\title{
EVALUASI AKTIVITAS ANTIOKSIDAN EKSTRAK ETANOL SPONS Aplysina sp. DIPESISIR PANTAI LEMBEH KOTA BITUNG
}

\section{EVALUATION OF ANTIOXIDANT ACTIVITY OF ETHANOL EXTRACT SPONGE Aplysina sp. ON THE COAST OF LEMBEH, BITUNG CITY.}

\author{
Hendra $^{1)}$, Adithya Yudistira ${ }^{1)}$, Surya Sumantri ${ }^{1)}$ \\ 1) Program Studi Farmasi FMIPA UNSRAT Manado, 95115 \\ *hendra05052@gmail.com
}

\begin{abstract}
Aplysina sp., is one of the marine biota, which forms the coral reefs that contain active compounds, whose percentage of activity is greater than the compounds produced by terrestrial plants. This study aims to analyze the antioxidant activity of the sponge Aplysina sp. Sponge sample Aplysina sp., obtained from the waters of the Lembeh Strait, Bitung. This research is an experimental laboratory by testing the ethanol extract of sponge Aplysina sp., with the DPPH method [1,1-diphenyl-2-picrilhidrazil] to analyze antioxidant activity using a spectrophotometer $U V$-Vis. The results of this study showed that the ethanolic extract of the sponge Aplysina sp. Lembeh straits waters have antioxidant activity in each concentration test. The highest concentration has an antidote to free radical activity by reaching a percentage of $24,83 \%$.
\end{abstract}

Keywords : Aplysina sp., Antioxidants, Ethanol, DPPH

\begin{abstract}
ABSTRAK
Spons Aplysina sp. merupakan salah satu biota laut penyusun terumbu karang yang mengandung senyawa aktif yang presentase keaktifannya lebih besar dibandingkan dengan senyawa-senyawa yang dihasilkan oleh tumbuhan darat.Penelitian ini bertujuan untuk menganalisis aktivitas antioksidan dari spons Aplysina sp. Sampel spons Aplysina sp. di peroleh dari perairan Selat Lembeh, Bitung. Penelitian ini merupakan eksperimental laboratorium dengan pengujian terhadap ektrak etanol spons Aplysina sp.dengan metode DPPH [1,1-difenil-2-pikrilhidrazil] untuk menganalisis aktivitas antioksidan dengan menggunakan sprektrofotometer UV-Vis. Hasil penelitian ini memperlihatkan ekstrak etanol spons Aplysina sp.di perairan selat lembeh mempunyai aktivitas antioksidan disetiap konsentrasi pengujiannya. Konsetrasi tertinggi memliki aktivitas penangkal radikal bebas dengan mencapai presentase $24,83 \%$.
\end{abstract}

Kata kunci :Aplysina sp., Antioksidan, Etanol, DPPH 


\section{PENDAHULUAN}

Selat Lembeh merupakan wilayah
perairan sempit dan memanjang yang memisahkan daratan utama Pulau Sulawesi dengan Pulau Lembeh. Secara geografis terletak diantara $1^{0} 33^{\prime}$ LU dan $125^{0} 7^{\prime}-125^{0} 17$ BT dan secara administratif masuk dalam wilayah kota Bitung, Sulawesi Utara. Karena letaknya di daerah Indo-Pasifik tropis, maka kawasan pesisir dan laut di perairan ini memiliki keanekaragaman hayati (biodiversity) yang sangat tinggi (Patty, 2015).

Salah satunya adalah spons, Spons adalah organisme laut yang memiliki potensi cukup besar dalam menghasilkan senyawa aktif.Spons diketahui menghasilkan senyawa bioaktif yang bermanfaat sebagai antibiotik, anti jamur, anti kanker, anti inflamasi, anti oksidan yang selama ini masih terus dieksplorasi (Abdul, 2003).

Untuk menjaga kelangsungan hidup dan pertahanan mengandung senyawa aktif yang presentase keaktifannya lebih besar dibandingkan dengan senyawa-senyawa yang dihasilkan oleh tumbuhan darat (Muniarsih et al., 1999).

Tubuh memiliki sistem pertahanan alami untuk menetralisir radikal bebas agar tidak berkembang dan menjadi berbahaya bagi tubuh. Pengaruh lingkungan dan kebiasaan buruk seperti radiasi ultraviolet, polusi, kebiasaan mengonsumsi "junk food" dan merokok, dapat membuat sistem pertahanan tubuh tidak mampu menghadapi radikal bebas yang berjumlah besar (Silalahi, 2006).

Antioksidan merupakan senyawa yang dapat menetralkan atau meredam radikal bebas, serta menghambat terjadinya oksidasi pada sel tubuh, sehingga dapat mencegah atau mengurangi terjadinya kerusakan sel. Penggunaan senyawa antioksidan berkembang dengan pesat, baik untuk makanan maupun pengobatan.Penggunaannya sebagai obat semakin meningkat dengan bertambahnyaa pengetahuan tentang aktivitas radikal bebas terhadap beberapa penyakit degeneratif seperti penyakit jantung, diabetes, kanker, inflamasi jaringan, kelainan imunitas dan penuaian dini (Ardiansyah, 2007).

Metode uji yang sering dipakai dalam menguji aktivitas antioksidan yaitu metode DPPH (1,1-difenil-2-pikrilhidrazil) secara spektrofotometri. Metode DPPH dipilih karena sederhana, mudah, cepat, dan peka serta hanya memerlukan sedikit sampel (Zou et al, 2004).

\section{METODOLOGI PENELITIAN \\ Waktu dan Tempat Penelitian}

Pengambilan sampel dilakukan di perairan Selat Lembeh, Kota Bitung. Penelitian ini dilaksanakan pada bulan Oktober 2018 -Juli 2020 di Laboratorium Farmakognosi, Laboratorium Fitokimia, dan Laboratorium Analisis Farmasi Fakultas Matematika dan Ilmu Pengetahuan Alam, Universitas Sam Ratulangi.

\section{Bentuk Penelitian}

Bentuk penelitian ini merupakan
penelitian yang menggunakan metode eksperimental laboratorium yang akan menguji aktivitas antioksidan dengan menggunakan metode DPPH (1,1-difenil-2-pikrilhidrazil) dari ekstrak spons Aplysina sp.

\section{Alat dan Bahan \\ Alat}

Alat-alat yang digunakan dalam penelitian ini yaitu masker, snorkel, fins, tabung oksigen, kamera, gunting, pisau, wadah botol air, cawan porselin, ziplok, sarung tangan, telenan, labu ukur $10 \mathrm{~mL}$ (pyrex), Erlenmeyer $200 \mathrm{~mL}$, cawan petri, corong, pipet tetes, mikro pipet, timbangan digital (AE ADAM), spatula, aluminium foil,oven, vortek, spektrofotometer UV-Vis.

\section{Bahan}

Bahan-bahan yang digunakan pada penelitian ini yaitu Spons Aplysina sp., etanol $96 \%$, kertas saring, tissue, aluminium foil, kertas label, serbuk Vitamin C p.a dan DPPH (1,1difenil-2-pikrilhidrazil).

\section{Prosedur Penlitian \\ Pengambilan Sampel}

Sampel spons Aplysina sp. diperoleh dari perairan selat Lembeh, Kota Bitung. Sempel diambil dengan menggunakan alat bantu (masker, snorkel, fins, tabung, oksigen, ziplok, pisau), kemudian dimasukkan dalam ziplok dan diberikan lebel. Kantong sampel dimasukkan kedalam kotak pendingin yang berisi es batu dan tidak terkena sinar matahari langsung. Lalu sampel dibawah ke Laboratorium Farmakognosi Program Studi Farmasi Universitas Sam Ratulangi.

\section{Preparasi Sampel}

Sampel yang didapat langsung dicuci kembali dan dipotong kecil lalu dimasukkan ke dalam wadah botol dengan menggunakan pelarut etanol $96 \%$ sebanyak $200 \mathrm{~mL}$. 


\section{Ekstraksi Sampel}

Sampel yang diperoleh sebanyak 430 gram dimaserasi dengan pelarut etanol $96 \%$ sebany ak $200 \mathrm{~mL}$ dengan 3 kali pengulangan selama 24 jam dengan sesekali dikocok. Hasil ekstraksi kemudian di saring menggunakan kertas saring $16 \times 16 \mathrm{~cm}$, kemudian diambil filtratnya dan residu dibuang. Filtrat tersebut dipekatkan dengan menggunakan oven pemanas untuk mendapatkan ekstrak kasar dari sampel.

\section{Pembuatan Larutan Stok}

Sebanyak 100mg ekstrak etanol spons Aplysina sp. dilarutkan dalam $100 \mathrm{~mL}$ etanol 96\% (1000 ppm). Dihitung dengan menggunakan rumus pengenceran, yaitu :

$$
\mathbf{V}_{1} \cdot \mathbf{M}_{1}=\mathbf{V}_{2} \cdot \mathbf{M}_{2}
$$

Selanjutnya larutan stok dibuat jadi beberapa konsentrasi yaitu 25, 50, 75, dan 100 $\mathrm{mg} / \mathrm{L}$ dengan menggunakan mikropipet dan ditambahkan etanol 96\% hingga mencapai tanda batas $(10 \mathrm{~mL})$, kemudian dipindahkan ke dalam tabung reaksi dan ditutup dengan menggunakan aluminium foil untuk digunakan pada perlakuan selanjutnya.

\section{Pembuatan Larutan DPPH}

Sebanyak $4 \mathrm{mg}$ DPPH ditimbang dan dilarutkan dalam etanol $96 \%$ sebanyak $100 \mathrm{~mL}$. Lalu diukur dalam spektrofotometri untuk mendapatkan absorbansi dan panjang gelombang maksimun dari larutan DPPH. Kemudian larutan stok DPPH dipipet menggunakan mikropipet sebanyak $2 \mathrm{~mL}$ dan ditambahkan pada masingmasing konsentrasi yang sudah dibuat dalam konsentrasi sampel spons Aplysina sp. dan Vitamin C p.a yaitu 25, 50, 75, dan $100 \mathrm{mg} / \mathrm{L}$. Lalu campuran larutan tadi divortex selama 3 detik. Sampel dibuat sebanyak 3 kali pengulangan.

\section{Pembuatan Larutan Vitamin C (p.a)}

Vitamin $\mathrm{C}$ p.a ditimbang sebanyak $10 \mathrm{mg}$. Kemudian, vitamin $\mathrm{C}$ p.a dilarutkan dalam etanol $96 \%$ sebanyak $10 \mathrm{~mL}$. Selanjutnya larutan stok vitamin $\mathrm{C}$ p.a dibuat dalam beberapa konsentrasi yaitu 25, 50, 75, dan $100 \mathrm{mg} / \mathrm{L}$ menggunakan mikropipet dan ditambahkan etanol 96\% hingga mencapai tanda batas $(10 \mathrm{~mL})$. Kemudian dipindahkan kedalam tabung reaksi dan ditutup menggunakan alumunium foil untuk digunakan pada perlakuan selanjutnya.

\section{Pengujian Larutan Kontrol DPPH dan Aktivias Antioksidan dengan Metode DPPH}

Larutan kontrol DPPH dan ekstrak etanol spons Aplysina sp. yang sudah dibuat, diuji pada spetrofotometer UV-Vis dengan panjang gelombang $517 \mathrm{~nm}$. Sampel diinkubasi selama 30 menit pada suhu $37^{\circ} \mathrm{C}$. Untuk mengetahui aktivitas dari penangkal radikal bebas tersebut, diuji pada spektrofotometer. Berubahnya warna ungu menjadi warna kuning menunjukkan efisiensi penangkal radikal bebas. Kemudian diamati perbandingannya dengan vitamin $\mathrm{C}$ p.a sebagai standar. Aktivitas penangkapan radikal bebas (persen inhibisi) dihitung sebagai persentase berkurangnya warna DPPH dengan menggunakan rumus :

$$
\% \text { inhibisi }=1-\frac{\text { Absorbansi sampel }}{\text { Absorbansi kontrol }} \times 100 \%
$$

\section{HASIL DAN PEMBAHASAN}

Uji aktivitas suatu tanaman maupun biota laut sangat penting dilakukan untuk mengetahui apakah dari tanaman atau biota laut tersebut terbukti memiliki aktivitas pengikatan terhadap radikal bebas. Pada penelitian ini, biota laut yang digunakan yaitu Spons Aplysina sp. Sebagai parameter pengujian antioksidan dilakukan dengan menggunakan metode uji DPPH $(1,1$ difenil-2-pikrihidrazil).

Metode DPPH merupakan metode yang sederhana, mudah, cepat dan peka serta hanya memerlukan sedikit sampel untuk evaluasi antioksidan. Prinsip dari metode ini adalah interaksi antioksidan dengan DPPH baik secara transfer elektron pada DPPH akan menetralkan karakter radikal bebas dari DPPH, jika semua elektron pada radikal bebas DPPH menjadi berpasangan maka warna larutan berubah dari ungu tua menjadi kuning terang. Karena karakteristik dari antioksidan sendiri adalah mudah memberikan elektron, semakin mudah memberikan elektron maka sifat antioksidannya semakin kuat. Perubahan warna ini mengakibatkan perubahan absorbansi pada panjang gelombang maksimum DPPH menggunakan spektrofotometri UV-Vis yang menjadi patokan.

Penentuan panjang gelombang maksimum larutan DPPH dilakukan dengan mengukur 
absorbansi larutan pada panjang gelombang 400$600 \mathrm{~nm}$. Hasil yang didapatkan pada penelitian ini adalah $517 \mathrm{~nm}$ dan memiliki absorbansi control 0,772 .

Sebelum melakukan pengujian larutan DPPH dilakukan pembuatan larutan stok. Larutan stok adalah larutan yang konsentrasinya dipekatkan atau ditinggikan dari konsentrasi media. Pada umumnya dinyatakan dalam kelipatan konsentrasi media yaitu 10x, 20x, 100x, bahkan 1000x konsentrasi media. Pada penelitian ini dilakukan pengujian dengan pengulangan konsentrasi 25, 50, 75, dan $100 \mathrm{mg} / \mathrm{L}$. Tujuan dari pembuatan larutan stok sendiri adalah untuk menghindari penimbangan yang berulang-ulang setiap kali membuat media. Kondisi simpan juga perlu diperhatikan, larutan yang sudah mengalami pengendapan tidak dapat digunakan lagi.Pengendapan biasanya terjadi bila kepekatan larutan terlalu tinggi. Oleh karena itu pengendapan larutan dapat dihindari dengan membuat larutan yang tidak terlalu pekat atau tidak menggunakan bahan campuran yaitu dengan membuat satu larutan stok hanya untuk satu jenis bahan.

Pengujian aktivitas antioksidan dalam penelitian ini menggunakan perbandingan $1: 1$ yang artinya $2 \mathrm{~mL}$ larutan DPPH dicampurkan dengan $2 \mathrm{~mL}$ larutan sampel (ekstrak etanol spons Aplysina sp. atau vitamin C) pada tiap konsentrasi yang berbeda-beda. Campuran DPPH dan ekstrak dibantu dengan perlakuan vortex selama 3 detik. Berkurangnya intensitas warna larutan DPPH tersebut dapat menunjukkan bahwa terjadi reaksi antara atom hidrogen yang dilepas oleh bahan uji dengan molekul radikal DPPH sehingga terjadi perubahan warna dari ungu menjadi kuning.

Setelah campuran dihomogenkan lalu diinkubasi dengan ditutup alumunium foil dengan suhu $37^{\circ} \mathrm{C}$ selama 30 menit. Hal ini dilakukan untuk menghindari kontaminasi dan mengoptimalkan aktivitas DPPH agar terjadi reaksi antara DPPH dengan sampel uji.Setelah diinkubasi, masing-masing ekstrak dilakukan pengukuran absorbansi dengan menggunakan spektrofotometer pada panjang gelombang serapan maksimum DPPH $517 \mathrm{~nm}$. Tiap konsentrasi dilakukan pengulangan sebanyak 3 kali pengulangan.

Pembanding yang digunakan sebagai kontrol postif adalah vitamin $\mathrm{C}$ p.a karena berfungsi sebagai antioksidan sekunder yaitu menangkap radikal bebas, mencegah terjadinya reaksi berantai, aktivitas antioksidannya sangat tinggi, mudah diperoleh dan vitamin $\mathrm{C}$ lebih polar dari vitamin yang lain.

Pengujian ini dilakukan untuk mengetahui aktivitas dari penangkal radikal bebas, di uji pada spektrofotometer. Hasil pengujian disajikan pada tabel dibawah ini:

Tabel 1.Hasil Pengukuran Absorbansi Aktivitas Antioksidan Ekstrak Etanol Apysina Sp. Dipesisir Pantai Lembeh, Kota Bitung.

\begin{tabular}{cccc}
\hline \multirow{2}{*}{ Konsentrasi } & $\begin{array}{c}\text { Pengulangan I } \\
\text { Ekstrak } \\
\text { Vit. C }\end{array}$ & $\begin{array}{c}\text { Pengulangan II } \\
\text { Ekstrak } \\
\text { Vit. C }\end{array}$ & $\begin{array}{c}\text { Pengulangan III } \\
\text { Ekstrak } \\
\text { Vit. C }\end{array}$ \\
\hline \multirow{2}{*}{$25 \mathrm{mg} / \mathrm{L}$} & 0.616 & 0,616 & 0,613 \\
& 0,004 & 0,043 & 0,044 \\
\hline \multirow{2}{*}{$50 \mathrm{mg} / \mathrm{L}$} & 0,599 & 0,607 & 0,612 \\
& 0,051 & 0,046 & 0,046 \\
\hline \multirow{2}{*}{$75 \mathrm{mg} / \mathrm{L}$} & 0,586 & 0,599 & 0,590 \\
& 0,045 & 0,048 & 0,045 \\
\hline \multirow{2}{*}{$100 \mathrm{mg} / \mathrm{L}$} & 0,579 & 0,588 & 0,575 \\
& 0,044 & 0,044 & 0,046 \\
\hline
\end{tabular}


Tabel 2.Hasil Perbandingan Pengujian Aktivitas Antioksidan Ekstrak Etanol Apysina Sp. Dipesisir Pantai Lembeh, Kota Bitung.

\begin{tabular}{ccccc}
\hline \multirow{2}{*}{ Konsentrasi } & $\begin{array}{c}\text { Penulangan I } \\
\text { Ekstrak } \\
\text { Vit. C }\end{array}$ & $\begin{array}{c}\text { Pengulangan II } \\
\text { Ekstrak } \\
\text { Vit. C }\end{array}$ & $\begin{array}{c}\text { Pengulangan III } \\
\text { Ekstrak } \\
\text { Vit. C }\end{array}$ & Rata-rata \pm SD \\
\hline \multirow{2}{*}{$25 \mathrm{mg} / \mathrm{L}$} & $20,30 \%$ & $20,30 \%$ & $20,60 \%$ & $20,40 \%$ \\
& $93,90 \%$ & $94 \%$ & $93,90 \%$ & $93,90 \%$ \\
\hline \multirow{2}{*}{$50 \mathrm{mg} / \mathrm{L}$} & $22,50 \%$ & $21,10 \%$ & $20,80 \%$ & $21,46 \%$ \\
& $92,90 \%$ & $93,60 \%$ & $93,60 \%$ & $93,90 \%$ \\
\hline \multirow{2}{*}{$75 \mathrm{mg} / \mathrm{L}$} & $24,10 \%$ & $22,50 \%$ & $23,60 \%$ & $23,40 \%$ \\
& $93,80 \%$ & $93,30 \%$ & $93,80 \%$ & $93,60 \%$ \\
\hline \multirow{2}{*}{$100 \mathrm{mg} / \mathrm{L}$} & $25 \%$ & $23,90 \%$ & $25,60 \%$ & $24,83 \%$ \\
& $93,90 \%$ & $93,90 \%$ & $93,60 \%$ & $93,80 \%$ \\
\hline
\end{tabular}

Pada hasil pengukuran tadi diperoleh absorbansi yang digunakan untuk menghitung persen inhibisinya atau persen perendaman senyawa antioksidan ekstrak etanol spons Aplysina sp. dan vitamin C p.a sebagai pembanding terhadap DPPH. Data dari hasil persen inhibisi ekstrak etanol spons Aplysina sp. dan vitamin $\mathrm{C}$ dapat dilihat pada Tabel 2. Hasil menunjukkan bahwa spons Aplysina sp. memiliki aktivitas antioksidan dengan rata-rata $20,40 \%$ pada konsentrasi $25 \mathrm{mg} / \mathrm{L}, \quad 21,46 \%$ pada konsentrasi $50 \mathrm{mg} / \mathrm{L}, 23,40 \%$ pada konsentrasi 75 $\mathrm{mg} / \mathrm{L}$, dan 24,83\% pada konsentrasi $100 \mathrm{mg} / \mathrm{L}$.

Manumpil (2019) mengungkapkan bahwa hasil pengujian perbandingan ekstrak spons Apysina sp. dan vitamin $\mathrm{C}$ menunjukkan bahwa aktivitas antioksidan ekstrak etanol spons Apysina sp. lebih rendah dibandingkan vitamin $C$, dengan rata-rata $43,66 \%$ pada konsentrasi $25 \mathrm{mg} / \mathrm{L}$, 44,23\% pada konsentrasi $50 \mathrm{mg} / \mathrm{L}, 45,36 \%$ pada konsentrasi $75 \mathrm{mg} / \mathrm{L}$, dan $46,13 \%$ pada konsentrasi $100 \mathrm{mg} / \mathrm{L}$. Rendahnya aktivitas antioksidan ini kemungkinan disebabkan oleh berbagai faktor, diantaranya karena metode ekstraksi yang digunakan kemungkinan tidak cukup menarik komponen kimia yang bersifat antioksidan dalam spons Aplysina sp. selain itu karena vitamin $\mathrm{C}$ merupakan senyawa murni sedangkan ekstrak etanol spons Apysina sp. masih merupakan senyawa campuran dan belum diketahui kandungan senyawanya yang bersifat antioksidan, dimana adanya senyawa yang tidak bersifat antioksidan kemungkinan bisa mempengaruhi aktivitas antioksidan ekstrak etanol spons Apysina sp. itu sendiri. Perbedaan kandungan antioksidan dengan jurnal tersebut diduga karena jumlah individu pada setiap kedalaman dan kondisi fisik kimia pada perairan diantaranya kecepatan arus, suhu, dan kecerahan.

\section{KESIMPULAN}

Berdasarkan dari hasil penelitian ini dapat disimpulkan bahwa ekstrak etanol spons Aplysina sp. yang diambil dari Perairan Selat Lembeh, Kota Bitung memiliki aktivitas antioksidan. Aktivitas tertinggi terlihat pada konsentrasi $100 \mathrm{mg} / \mathrm{L}$ dengan nilai presentase $24,83 \%$.

\section{SARAN}

Perlu dilakukan penelitian lebih lanjut untuk mengetahui senyawa aktif yang terkandung dalam spons Aplysina sp. dan pengujian aktivitas antioksidan dengan metode lain dan membandingkan hasilnya dengan penelitian ini.

\section{DAFTAR PUSTAKA}

Abdul., M. 2003. Peranan radikal bebas dan antioksidan dalam kesehatan dan penyakit.Http://www.intisari.com/radika l.html. Diakses 28 November 2019

Manumpil, A. 2019. Uji Aktivitas Antioksidan Ekstrak Etanol Spons Aplysina sp. Dari Perairan Selat Lembeh Kota Bitung. [Skripsi]. Fakultas Matematika dan Ilmu Pengetahuan Alam UNSRAT, Manado.

Ardiansyah. 2007. Antioksidan dan Peranannya Bagi Kesehatan. Http: //www. Beritaiptek.com. Diakses 07 Januari 2020.

Muniarsih, T, dan Rachmaniar, R. 1999. Isolasi Substansi Bioaktif Antimikroba dari Spons Asal Pulau Pari Kepulauan Seribu. Prosiding Seminar Bioteknologi Kelautan Indonesia I '98. Jakarta 14 15 Oktober 1998: Lembaga Ilmu Pengetahuan Indonesia, Jakarta. 
Silalahi, J. 2006. Makanan Fungsional. Kanisius, Jogjakarta.

Simon I. Patty, 2015. Karakteristik Fosfat, Nitrat dan Oksigen Terlarut diperairan Selat Lembeh, Sulawesi Utara. Jurnal Pesisir dan Laut Tropis, 5: 1-2.

Zou, Y., Lu, Y. dan Wei, D. 2004. Antioxidant activity of Flavonoid-rich extract of Hypericum perforatum, $\mathrm{L}$ in vitro. Journal of Agriculture and Food Chemistry, 52:5032-50. 